Part of Journal of Research of the National Bureau of Standards, Volume 17, December 1936

\title{
DIFFERENCES IN LIMES AS REFLECTED IN CERTAIN PROPERTIES OF MASONRY MORTARS
}

\author{
Lansing S. Wells, Dana L. Bishop, and David Watstein
}

\section{ABSTRACT}

A survey was made of commercial quicklimes and hydrated limes with respect to some physical properties of importance to their use in mortars. Measurements of soundness, plasticity, and flow after suction were made on putties prepared from the quicklimes and hydrated limes and flows after suction were measured on cement-lime mortars prepared from the lime putties. It was found that the properties of the different limes varied widely. Flows after suction of lime mortars were roughly proportional to the plasticities of the lime putties. The properties of a lime were found to be more important than the proportions of lime used in preparing cement-lime mortars having high flows after suction.

\section{CONTENTS}

I. Introduction

II. Materials_._. 895

1. Limes... 895

2. Cements

3. Sand

III. Tests and results. 896

1. Limes

(a) Soundness _... 896

(b) Plasticity.... 898

2. Mortars _._.

(a) Proportioning, mixing, and testing

(b) Relation between plasticity of lime putties and flow after suction of lime-sand mortars _........... 901

(c) Effect of different limes on flow of cement-lime-sand mortars.

IV. Summary

\section{INTRODUCTION}

Considerable attention has been paid to the effect of proportioning the constituents of cement-lime mortars upon the properties of the mortars, often with too little consideration of the differences in the properties of the constituents. The investigation herein described pertains primarily to differences in the properties of lime putties made from various limes and the relation to the differences in the resulting properties of lime and cement-lime mortars containing these putties.

\section{MATERIALS}

\section{LIMES}

The investigation included 43 limes, representing commercial products from various parts of the United States. These samples consisted of 19 pulverized quicklimes and 24 hydrated limes. The 
quicklimes included 15 classed as high-calcium limes and 4 as dolomitic. The hydrated limes included 17 high-calcium and 7 dolomitic limes. The authors are indebted to the National Lime Association for cooperation in securing many of these samples.

\section{CEMENTS}

Two cements were used; a typical portland cement with a specific surface of $1,750 \mathrm{~cm}^{2} / \mathrm{g}$ as determined with the Wagner turbidimeter, ${ }^{1}$ and a high-early-strength cement with a specific surface of 2,770 $\mathrm{cm}^{2} / \mathrm{g}$.

\section{SAND}

Clean Potomac River mortar sand was used in all tests of mortars. The sieve analysis of this sand was as follows:

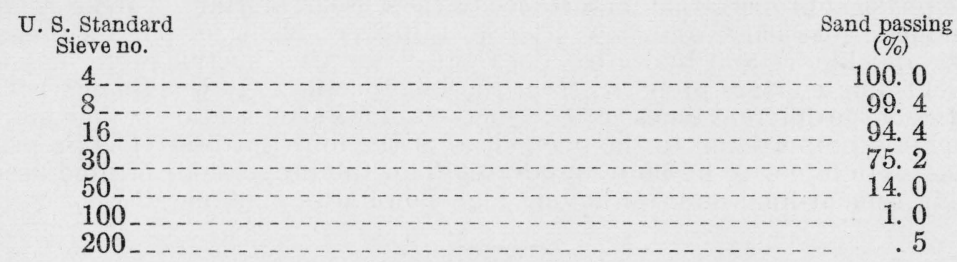

\section{TESTS AND RESULTS}

\section{LIMES}

(a) SOUNDNESS

Both the hydrated limes and pulverized quicklimes were tested for soundness according to the procedure given in the Tentative Methods of Physical Test for Limestone, Quicklime, and Hydrated Lime, ASTM designation: C 110-34T. ${ }^{2}$ This method consists essentially in steaming (120-lb/in. ${ }^{2}$ pressure) specimens made of two parts of limeputty (whether made from quicklime or hydrated lime) and one part of quick-setting calcined gypsum. Under the condition of the test, particles in the lime which might under ordinary atmospheric condition require months or years to produce "pits" or "pops" in a plastered surface, are so accelerated in their hydration with consequent expansion that crater-like holes are produced in the test specimens in a relatively few minutes. Tests of panels made in the laboratory have shown good agreement between the actual development of pops and results of the autoclave test. ${ }^{3}$

All hydrated limes were made into stiff putties and allowed to soak, samples being taken at the end of 1 day and 3 days, respectively, for determination of soundness. The pulverized quicklimes were slaked in such a manner that the reaction progressed at or near the boiling point of water resulting in the formation of stiff putties, samples of which, in turn, were also soaked for periods of 1 day and 3 days before testing for soundness.

The results given in table 1 show that 7 of the 24 hydrated limes and 8 of the 19 pulverized quicklimes gave putties classified as unsound after soaking 1 day. At the end of 3 days of soaking putties from 4 of the hydrated limes and from 4 of the quicklimes were unsound.

1 Proc. Am. Soc. Testing Materials 33, II, 553 (1933).

2 Proc. Thirty-Seventh Annual Meeting 34, part I, 754 (1934).

3D. L. Bishop, A modified test for the "soundness" of finishing lime, Rock Products 34, 67-69 (July 18, 1931). 
TABLE 1.-Results of soundness and plasticity determinations on putties made from hydrated limes and quicklimes soaked 1 day and 3 days, together with "flow after 1 -minute suction" of lime-sand mortars made from these putties

\begin{tabular}{|c|c|c|c|c|c|c|}
\hline \multirow{2}{*}{ Lime no. } & \multicolumn{2}{|c|}{$\begin{array}{c}\text { Soundness at end } \\
\text { of }-\end{array}$} & \multicolumn{3}{|c|}{ Plasticity- } & \multirow{2}{*}{$\begin{array}{l}\text { "Flow after } \\
\text { suction" of } \\
\text { lime-sand } \\
\text { mortars } \\
(1: 6 \text { by wt) } \\
\text { after } 1 \\
\text { minute }\end{array}$} \\
\hline & 1 day & 3 days & $\begin{array}{l}\text { At end } \\
\text { of } 1 \text { day }\end{array}$ & $\begin{array}{l}\text { At end } \\
\text { of } 3 \text { days }\end{array}$ & $\begin{array}{l}\text { At time } \\
\text { of flow } \\
\text { tests }\end{array}$ & \\
\hline
\end{tabular}

HYDRATE: HIGH $\mathrm{Ca}$

\begin{tabular}{|c|c|c|c|c|c|c|}
\hline 1 & $\begin{array}{r}{ }^{1} S \\
S \\
S \\
S \\
\end{array}$ & $\begin{array}{l}S \\
S \\
S \\
S \\
U\end{array}$ & $\begin{array}{r}110 \\
270 \\
100 \\
300 \\
80\end{array}$ & $\begin{array}{l}110 \\
280 \\
110 \\
350 \\
120\end{array}$ & $\begin{array}{l}110 \\
280 \\
110 \\
300 \\
120\end{array}$ & $\begin{array}{r}75 \\
104 \\
81 \\
108 \\
85\end{array}$ \\
\hline $\begin{array}{l}6 \\
6 \\
\end{array}$ & $\begin{array}{l}U \\
S \\
S \\
S \\
S\end{array}$ & $\begin{array}{l}S \\
S \\
S \\
S \\
S \\
S\end{array}$ & $\begin{array}{l}120 \\
240 \\
180 \\
100 \\
420\end{array}$ & $\begin{array}{l}120 \\
250 \\
140 \\
120 \\
440\end{array}$ & $\begin{array}{l}120 \\
240 \\
140 \\
120 \\
330\end{array}$ & $\begin{array}{r}73 \\
91 \\
96 \\
86 \\
100\end{array}$ \\
\hline 112 & $\begin{array}{l}U \\
S \\
U \\
S \\
S\end{array}$ & $\begin{array}{l}U \\
S \\
S \\
S \\
S\end{array}$ & $\begin{array}{r}150 \\
130 \\
180 \\
120 \\
70\end{array}$ & $\begin{array}{r}140 \\
140 \\
210 \\
120 \\
70\end{array}$ & $\begin{array}{l}120 \\
160 \\
180 \\
120\end{array}$ & $\begin{array}{r}89 \\
99 \\
96 \\
79 \\
\end{array}$ \\
\hline 16 & $\stackrel{S}{S}$ & $\underset{S}{S}$ & $\begin{array}{l}50 \\
80\end{array}$ & $\begin{array}{r}120 \\
80\end{array}$ & & \\
\hline
\end{tabular}

HYDRATED: DOLOMITIC

$\left.\begin{array}{r|r|r|r|r|r|r}\hline 19 & S & S & 430 & 440 & 290 \\ 310 & 103 \\ 95 \\ 19\end{array}\right)$

QUICKLIME: HIGH $\mathrm{Ca}$

\begin{tabular}{|c|c|c|c|c|c|c|}
\hline 26 & $\begin{array}{l}U \\
S \\
U \\
S \\
S\end{array}$ & $\begin{array}{l}U \\
S \\
U \\
S \\
S\end{array}$ & $\begin{array}{r}>600 \\
350 \\
160 \\
>600 \\
>600\end{array}$ & $\begin{array}{r}>600 \\
360 \\
180 \\
>600 \\
>600\end{array}$ & $\begin{array}{r}220 \\
230 \\
130 \\
430 \\
>600\end{array}$ & $\begin{array}{l}108 \\
114 \\
101 \\
111 \\
114\end{array}$ \\
\hline $\begin{array}{l}30 \\
31 \\
32 \\
33\end{array}$ & $\begin{array}{l}S \\
S \\
S \\
S \\
S\end{array}$ & $\begin{array}{l}S \\
S \\
S \\
S \\
S \\
S\end{array}$ & $\begin{array}{r}>600 \\
>600 \\
>600 \\
180 \\
>600\end{array}$ & $\begin{array}{l}>600 \\
>600 \\
>600 \\
180 \\
>600\end{array}$ & $\begin{array}{r}>600 \\
>600 \\
>600 \\
150 \\
>600\end{array}$ & $\begin{array}{l}113 \\
117 \\
115 \\
111 \\
113\end{array}$ \\
\hline $\begin{array}{l}35 \\
36 \\
36 \\
38 \\
39\end{array}$ & $\begin{array}{l}U \\
S \\
S \\
S\end{array}$ & $\begin{array}{l}S \\
S \\
S \\
S\end{array}$ & $\begin{array}{r}130 \\
>600 \\
>600 \\
250 \\
550\end{array}$ & $\begin{array}{r}150 \\
>600 \\
>600 \\
250 \\
540\end{array}$ & 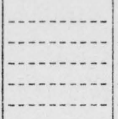 & 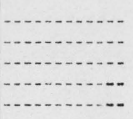 \\
\hline
\end{tabular}

QUICKLIME: DOLOMITIC

\begin{tabular}{|l|l|l|r|r|r}
\hline 40 & $U$ & $S$ & 160 & 180 & 150 \\
\hline 42 & $U$ & $S 60$ & 340 & 94 \\
\hline
\end{tabular}

$1 \mathrm{~S}=$ Sound.

${ }_{2} U=$ Unsound. 
(b) PLASTICITY

Portland cement mortars, in general, have the disadvantage as masonry materials of being harsh to work. Lime is often added with the idea of improving the plasticity and water-retaining power of the mortar mix, considerable attention generally being paid to the proportions of the mix and little or none to the plasticity or water-retaining power of the lime. Accordingly, plasticity determinations were made of stiff lime putties prepared from the hydrated limes and pulverized quicklimes by the method previously described, using the Emley plasticimeter, the instrument accepted by the lime industry for ascertaining the plasticity of lime. ${ }^{4}$

The Emley plasticimeter measures the torque of a steel disk against a revolving pat of lime putty as the putty stiffens on a standardized porous base-plate. It can be seen from the equation used to evaluate the plasticity, namely $P=\sqrt{F^{2}+(10 t)^{2}}$, where $P$ is the plasticity, $F$ the torque reading, and $t$ the time in minutes, that the longer the putty remains on the base-plate without stiffening the greater the plasticity. Thus, the plasticimeter indirectly gives information relative to the water-retaining properties of a lime putty and its troweling qualities, factors which are of concern to both plasterers and masons.

At the time the tests were made the putties were brought to standard consistency by the gradual addition of water accompanied by vigorous stirring-thus assuring a maximum plasticity of the putty, a procedure necessary to obtain consistent results.

The plasticity values, shown in table 1 and obtained with putties soaked for 1 day and 3 days before testing, varied from 50 to more than 600 . The highest values were obtained with putties prepared from pulverized quicklimes and the lowest with those from hydrated limes.

How much greater than 600 the plasticity values of some of the very plastic quicklime putties were could not be determined definitely for the following reasons. In general the very plastic putties when brought to standard consistency contain more water than do nonplastic putties (plasticity less than 200). Even though they give up their water less readily to the porcelain base-plate of the plasticimeter than do the nonplastic putties, sufficient water has entered the baseplate at the end of an hour so that further stiffening of the putties takes place at a still further reduced rate. Because the absorption capacity of the base-plate is limited the instrument is not particularly suited to distinguish differences in very high plasticity values. Consequently, it seemed best to indicate merely that the plasticity values of such putties were greater than 600 rather than to ascribe exact values.

For very plastic limes it has been shown that the determination of the time of decided stiffening of the putty is largely the determining factor in the ultimate plasticity value. For nonplastic limes, where $t$ is small, the value of $F$ in the equation for calculating plasticity becomes of increasing importance. Since nonplastic lime putties, in general, give high $F$ values, the plasticity value $P$ is raised relatively more than that of the plastic putties. Nevertheless, many lime putties, especially those prepared from hydrated limes, have plasticity

\footnotetext{
4 Federal Specification SS-L-351 for Lime; Hydrated (for) Structural Purposes. Also Tentative Methods for Physical Test for Limestone, Quicklime, and Hydrated Lime, ASTM designation: C 110-34T, Proc. Thirty-Seventh Annual Meeting, Am. Soc. Testing Materials 34, I, 754 (1934).
} 
values below 200 (the arbitrary minimum value for a plastic putty), and there are indications that their plasticity would be even less than that calculated were it not for the factor mentioned.

The above discussions have been given to point out the great differences in the plasticities of lime putties rather than to emphasize the difficulties in securing exact values of plasticity at the extremes. Even with these difficulties the instrument is useful for classifying lime putties as plastic or nonplastic. Exact plasticity values of lime putties over the entire range become of importance, however, when plasticity is considered as a function of some other property.

The performance of the plasticimeter, especially at the point of separation of the plastic from nonplastic putties (i. e., 200), is illustrated in figure 1. That the plasticity of mixtures of two lime putties is a

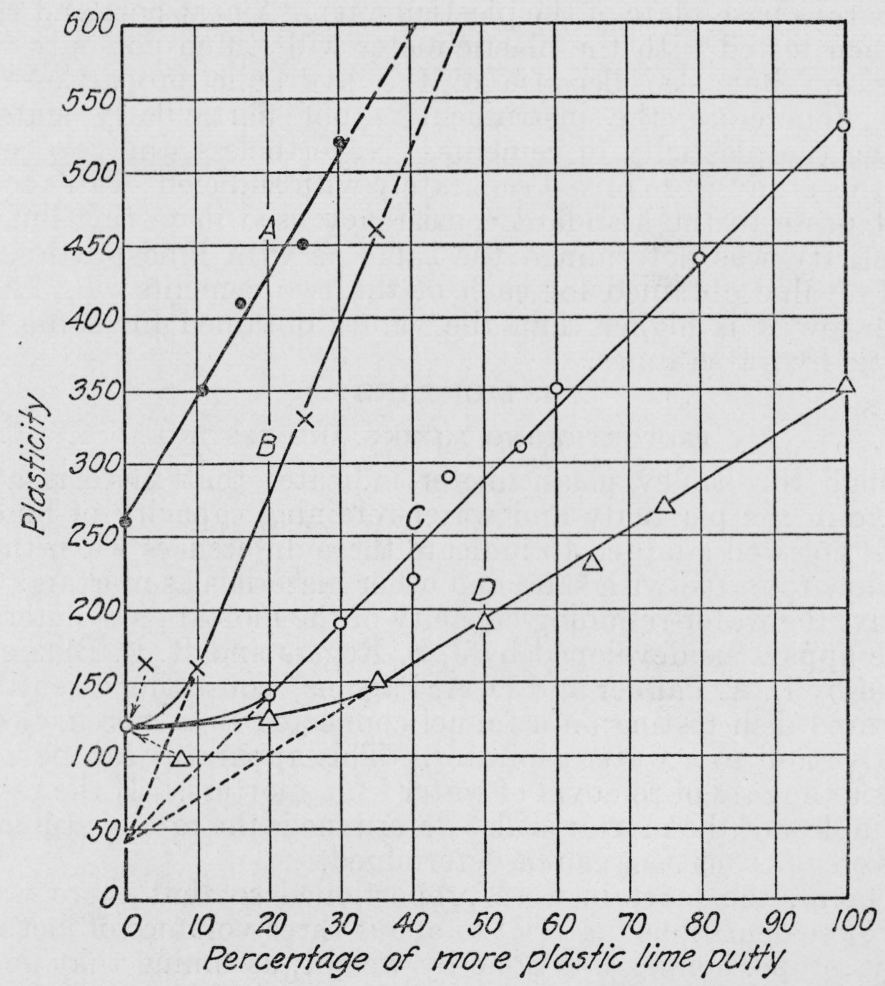

FIGURe 1.-Effect on plasticity of adding a more plastic lime putty to one less plastic. straight-line function when the plasticity is greater than 150 is indicated in this figure wherein the plasticity is plotted against the percentage of the more plastic lime putty. Line $A$ shows the increase in plasticity resulting from the addition of a very plastic putty to one having a plasticity of $260 . B, C$, and $D$ show the increases when three plastic lime putties are mixed with a nonplastic putty. Above about 150 it can be seen that the plasticities of the mixtures of the three plastic limes with the nonplastic lime appear to be three straight lines which upon extrapolation downward indicate that the nonplastic lime putty should have a plasticity value of 40 . The value obtained with the plasticimeter, however, was 120 . On the other hand, lines $A$ and 
$B$, if extrapolated upward, would indicate that the plasticities of the two very plastic limes used in preparation of these two series of mixtures were far in excess of 600 , being roughly twice that value.

It is often believed that the plasticity of lime putties always increases as the time of soaking is increased. Table 1 shows that in a few cases the plasticity increased with soaking from 1 to 3 days, in others there was no improvement, and some showed an actual decrease in plasticity. Consequently, the plasticity was determined also 3 to 4 weeks later at the time the flow tests were made on lime-sand mortars. These values, given under the column heading "plasticity at time of flow tests", show that in many instances the plasticity of the putties had decreased considerably.

As mentioned previously, lime putties stiffen as water is removed by the porous base-plate of the plasticimeter. A neat portland cement paste when tested with the plasticimeter will stiffen not only for the same reason but also because of the hydraulic properties of the cement. Therefore, the instrument is not particularly suited for measuring the plasticity of cements. Nevertheless, the two cements used in this study were mixed separately with sufficient water to bring the neat paste to the standard consistency used in testing limes and the plasticity was determined the same as with lime putties. The plasticity value obtained for each of the two cements was 120 , and although low it is higher than the values obtained for some of the nonplastic hydrated limes.

\section{MORTARS}

(a) PROPORTIONING, MIXING, AND TESTING

Although the Emley plasticimeter indicates that there is a great difference in the plasticity and water-retaining capacity of lime putties, it is not well adapted to indicate these differences when the putties are incorporated with sand and other materials as mortars. Consequently, the water-retaining capacity of the mortars was determined with the apparatus developed by J. S. Rogers and R. L. Blaine ${ }^{5}$ and described by L. A. Palmer and D. A. Parsons, ${ }^{6}$ consisting essentially of a perforated dish resting on a funnel connected to a mercury-column relief valve and to a water aspirator. This apparatus can be used to determine the rate of removal of water from mortars. If the resulting change in flow of the mortar is also determined, the rate of stiffening of mortars on a porous base can be determined.

In general, the mortars were proportioned so that there was one volume of cementitious material to about three volumes of loose sand. Actually, proportioning was done by weight, assuming that portland cement weighs $94 \mathrm{lb} / \mathrm{ft}^{3}$, dry hydrated lime, $40 \mathrm{lb} / \mathrm{ft}^{3}$, and that $1 \mathrm{ft}^{3}$ of loose damp sand contains $80 \mathrm{lb}$ of dry sand. For the sake of brevity, cement is indicated by the latter $C$, lime by $L$, and sand by $S$. In preparing the lime-sand mortars, lime putty, containing the equivalent of $100 \mathrm{~g}$ of dry hydrate, and $600 \mathrm{~g}$ of dry sand were mixed with a spatula, adding water gradually and stirring vigorously (to develop maximum plasticity) until the desired consistency had been attained. The flow was then determined by measuring the percentage increase in diameter of a mass of mortar on a standard 10-in flow table, ${ }^{7}$ dropping the table top through a height of 0.5 in 25 times in 15 seconds. The mortar mix was finally adjusted with water until several determina-

$\checkmark$ Investigation of commercial masonry cements, J. Resea1 ch NBS 13, 811-849 (1934) R P746.

F. Rate of stiffening of mortars on a porous base, Rock Products 35 , No. 18, 18-24 (1932).

7 Federal Specification Hydraulic Cements: Methods of Sampling, Inspection and Testing, SS-C-158 (September 30, 1936). 
tions showed an average flow of 130 , individual variations being 10 or less. The cement-lime-sand mortars were also stirred vigorously and adjusted to a flow of 130 percent. Vigorous stirring of cementsand mortars was not as essential as in the case of mortars containing lime.

The mortars thus prepared were placed in the cup of the filtration device, spread gently to avoid compacting, and leveled even with the rim. A suction equivalent to a head of 2 in. of mercury was then applied. Immediately after the suction period the mortar was transferred back to the flow table cone and the "flow after suction" determined.

A few experiments were also made to observe how much the flow of lime-sand mortars was decreased when spread on sand-lime bricks in the approximate thickness of a mortar joint. The mortars were first brought to a flow of 130 percent and then placed in a metal form

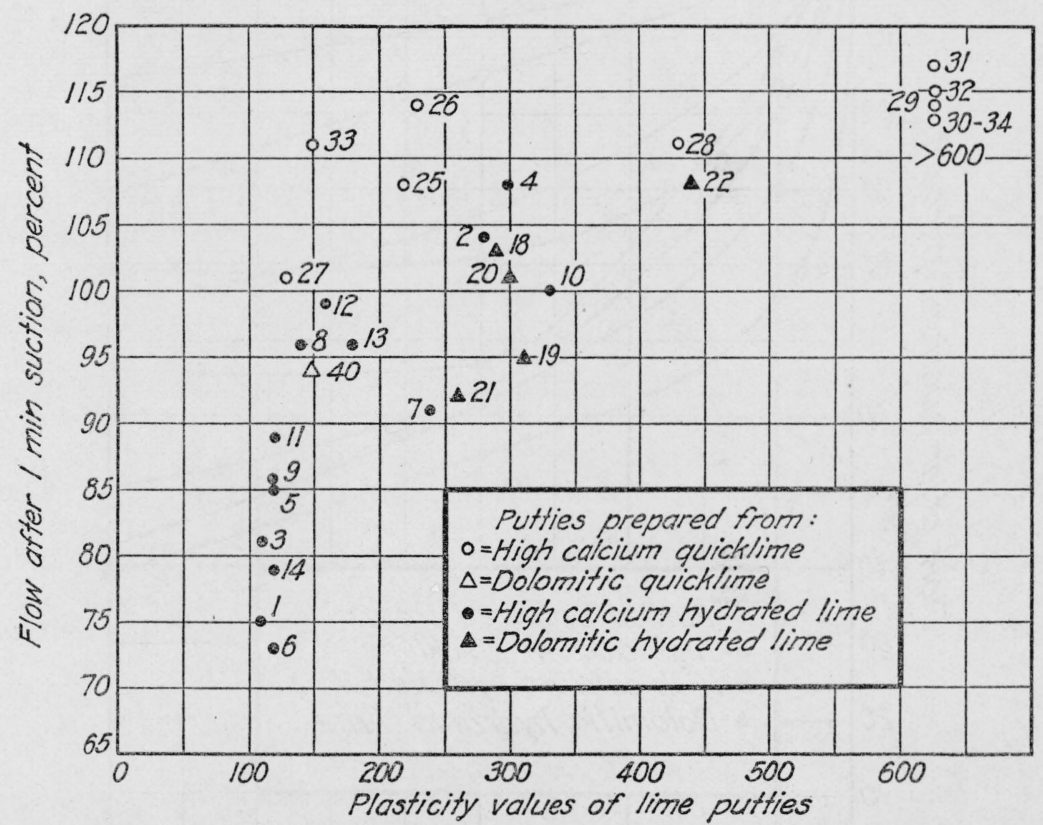

Figure 2.-Relation between flow of lime-sand mortars (adjusted to a flow of 130 percent) after 1 minute of suction and plasticity of lime putties.

( $8 \mathrm{in}$. by $3 \frac{3 / 4}{\mathrm{in}}$. by $\frac{5}{8}$ in.) resting on a flat side of the brick. The mortar was "struck off" and after 10 minutes the form was lifted and the mortar scraped from the brick into the cone of the flow table and the flow again determined. The bricks used in the tests had an average 5 -hour cold absorption of $9.1 \pm 0.1$ percent, by weight.

(b) RELA TION BETWEEN PLASTICITY OF LIME PUTTIES AND FLOW AFTER SUCTION OF LIME-SAND MORTARS

Figure 2 shows the flows resulting after 1 minute of suction of limesand mortars (initial flow of 130) plotted against the plasticity of the lime putties used in preparing the mortars. The figure shows that there is a large spread in the flows after suction (73 to 117 percent) and that none of the more plastic limes gave the lower values for the flow 
after suction. In general, mortars containing putties prepared from the pulverized quicklimes gave higher flows after suction than did those containing putties prepared from the hydrated limes. All of the lime putties having plasticity values between 110 and 120 formed mortars having flows after suction of less than 90 percent. It is these nonplastic putties which appear to have even lower extrapolated plasticity values than those indicated by the Emley plasticimeter (see fig. 1). Had these lower extrapolated values in plasticity (40 to 50 instead of 110 to 120 ) been plotted in figure 2 against the flow after suction, it would have been more evident that the flow after suction of a limesand mortar is dependent on the plasticity of the putty used in pre-

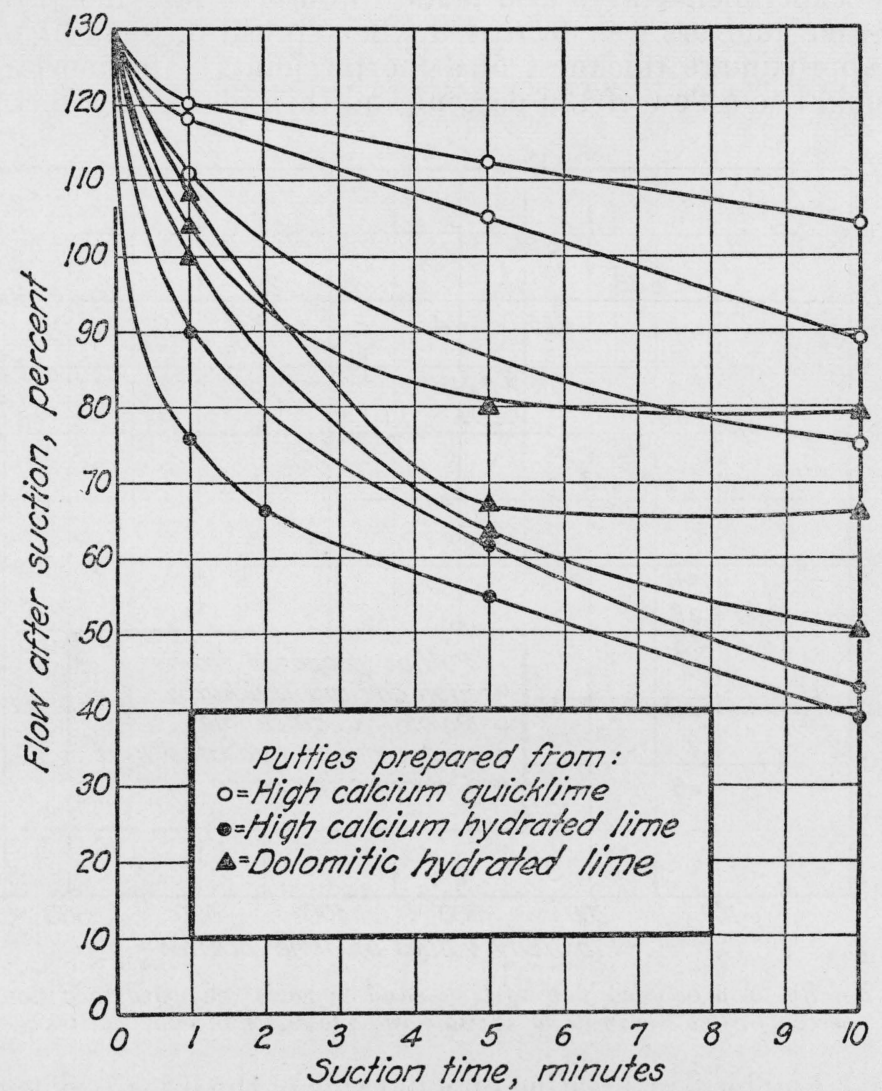

Figure 3.-Relation between percentage of flow of lime-sand mortars after suction and time of suction in minutes.

paring the mortar. Figure 2 shows also that the use of putties having high plasticity values will insure mortars of high flow after suction.

The rates of stiffening of eight lime-sand mortars are indicated in figure 3 by the percentage of flow at increasing time of suction. The eight lime putties used in preparing the mortars were chosen because they gave a wide range in plasticity values and flow after 1 minute of suction. The results confirm, in general, those obtained by Palmer and Parsons ${ }^{8}$ in that the mortars made from putties prepared from

8 Rate of stiffening of Mortars on a porous base, Rock Products 35, no. 18, 18-24 (1932). 
quicklimes do not decrease in flow as rapidly as those prepared from hydrated limes.

Figure 4 shows the flows resulting after 10 minutes, suction of limesand mortars plotted against the plasticity of the lime putties at the

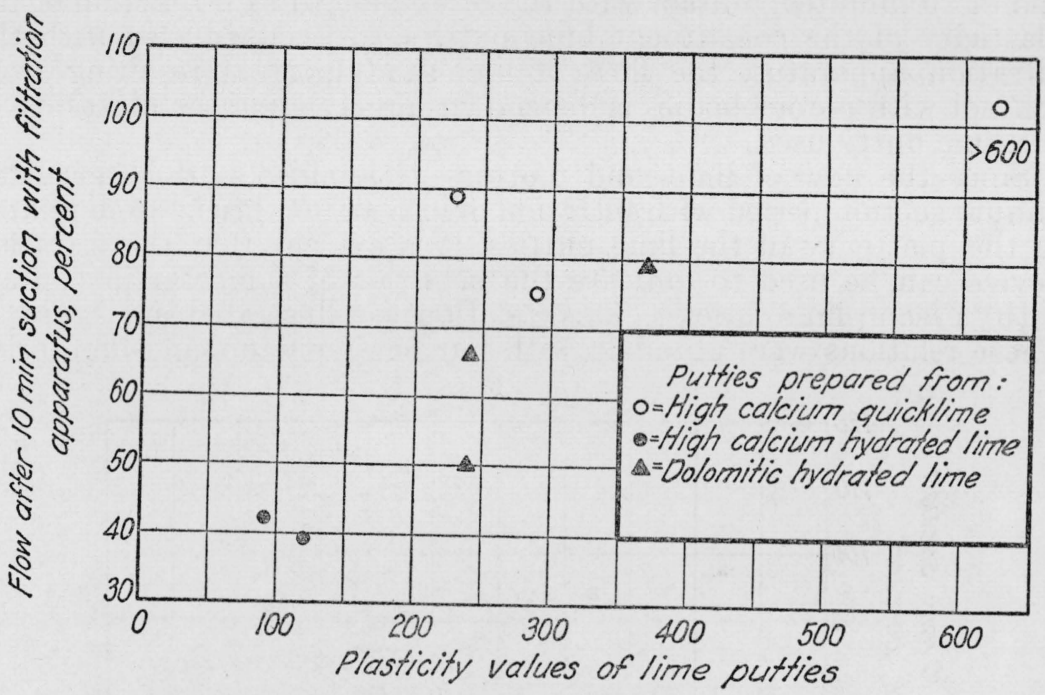

FIGURE 4.-Relation of flow of lime-sand mortars after 10 minutes' suction to plasticity of the lime putty used in preparing the mortars to an initial flow of 130 percent.

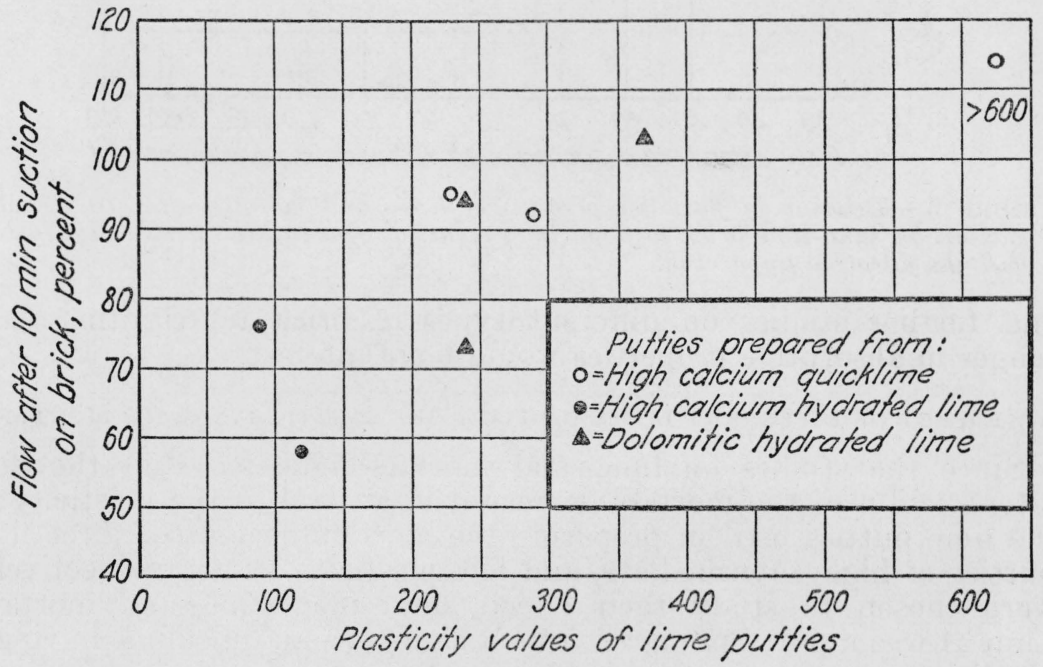

FIGURE 5.-Relation of flow of lime-sand mortars after 10 minutes' contact on sandlime brick to plasticity of the lime putty used in preparing the mortars to an initial flow of 130 percent.

time they were used in preparing the mortars. This plot shows, as illustrated by figure 2 , that the flow after suction of a lime-sand mortar in general increases as the plasticity of the limes used in preparing the mortars increases. 
These same lime-sand mortars were used also to determine how much the flow was decreased when they were spread on bricks in the approximate thickness of a mortar joint according to the procedure previously outlined. Figure 5 shows the flows of the mortars at the end of 10 minutes' contact with the brick plotted as a function of the plasticity of the constituent lime putties. As shown also with the filtration apparatus, the flow of lime-sand mortars resulting from contact with porous bodies is dependent largely upon the plasticity of the lime putty used.

Since the flow of lime-sand mortars determined both after a ten minute suction period with filtration device and on bricks were related to the plasticity of the lime putties, it is evident that the filtration device can be used to indicate the behavior of a mortar in contact with a sand-lime brick. This relation is illustrated in figure 6 . These relations were obtained with but one make of sand-lime brick

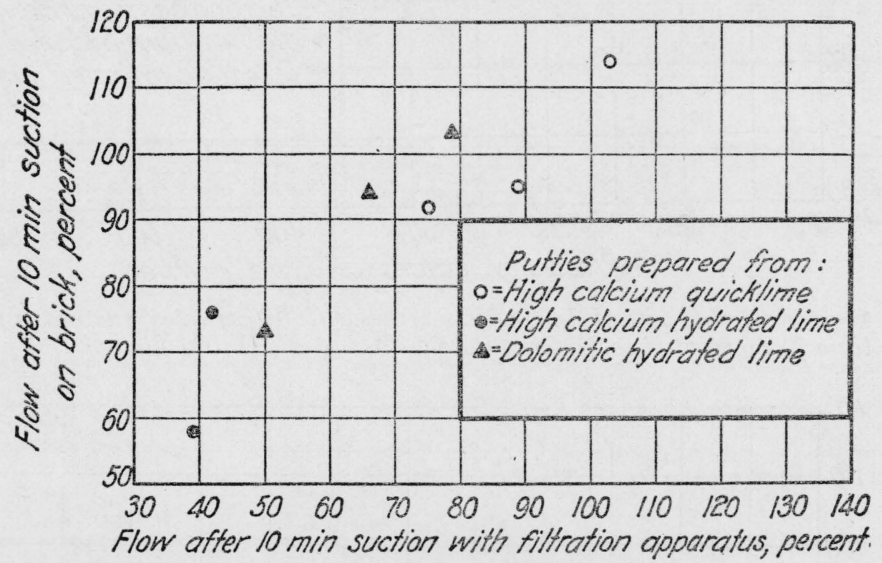

Figure 6.-Relation of flow (in percent) of lime-sand mortars after 10 minutes' suction on sand-lime brick to flow (in percent) obtained after 10 minutes' suction with the filtration apparatus.

and further studies on different types of brick representing wide ranges in absorptive properties would be of interest.

(c) EFFECT OF DIFFERENT LIMES ON FLOW OF CEMENT-LIME-SAND MORTARS

Since the studies on lime-sand mortars indicated that the flow after suction of the mortars decreased in general as the plasticity of the lime putties used in preparing the mortars decreased, three lime putties of high, intermediate, and low plasticity values, respectively, were chosen to study their effects on cement-lime-sand mortars. Lime $A$ was a putty prepared from a high-calcium quicklime having a plasticity value greater than 600 ; lime $B$ a putty from a high-calcium hydrated lime with a plasticity value of 280 ; and lime $C$ a nonplastic high-calcium hydrated lime putty with a plasticity value of 120 .

Figure 7 shows the change in flow after suction resulting from the addition of increasing amounts of the three limes to portland cement $A$. The proportions of the constituents of the mortar are indicated both on a weight and volume basis. A factor worthy of note is that the kind of lime used and manner of using are of more importance in 
securing a high flow after suction than is the proportioning. Thus, the relatively small quantity of lime putty $A$ in the mortar $1 C: 0.25 \mathrm{~L}: 3 S$ by volume increased the flow after suction of a straight cement-sand mortar (1C:3S by vol.) from 46 to 87 , a value greater than that of the straight lime-sand mortar prepared from putty $C$. When lime $C$ was not soaked to make a putty but was added as the dry hydrate to the mortar it gave a still lower value. Also, when added in this way in preparing a cement-lime-sand mortar (a common practice), lime $C$ increased the flow after suction but slightly. The increase in flows between a $1 C: 1 L: 6 S$ by volume and a $1 C: 2 L: 9 S$ by volume resulting from an increase in the proportions of both lime $C$ (not soaked) and lime $A$ are negligible as compared to the difference

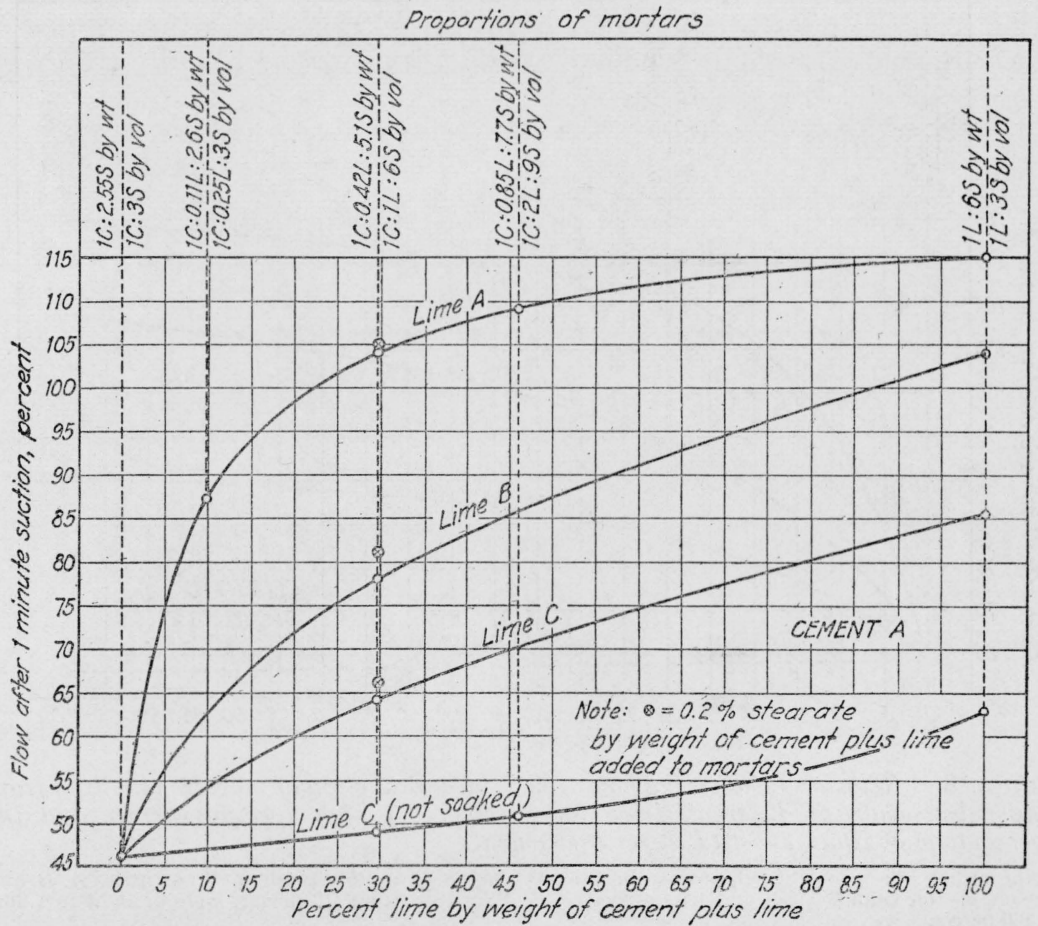

FIGURE 7.-Relation between the flow after 1 minute suction of mortars resulting from the substitution of different limes for a typical portland cement and the percentage of limes substituted for the cement.

Specific surface of cement $A$ was $1,750 \mathrm{~cm}^{2} / \mathrm{g}$ and plasticities of lime putties $A, B$, and $C$ were greater than 600,280 , and 120 , respectively. Prior to suction all mortars were brought to a flow of 130 percent.

obtained with the use of lime $A$ in preference to lime $C$ (either soaked or not soaked).

Figure 7 shows also that the addition of 0.2 percent of stearate increased but little the flow after suction of the mortars $1 C: 1 L: 6 S$ by volume using putties $A, B$, and $C$.

The flows after suction of mortars made by adding putties $A, B$, and $C$ to a cement-sand mortar made with the cement $B$, are shown in figure 8. Comparison of figure 8 with figure 7 shows that with the use of a cement of high specific surface (cement $B$ ), the flow after 
suction of a cement-sand mortar increases over that obtained by use of a typical portland cement (cement $A$ ). This increase, however, is small in comparison with that obtained with a lime putty similar to lime $A$. The addition of only 0.25 parts by volume ( 0.11 by weight) of this lime increased the flow after suction of the typical portland cement-sand mortar more than twice that attained when the highearly-strength cement $B$ was substituted for cement $A$ in the $1 C: 3 S$ mortar. The flow after suction of mix $1 C: 1 L: 6 S$ by volume was practically the same $(105 \pm 1)$ when both of these cements were used with lime $A$. Figure 8 shows also that the flow after 1-minute suction of the cement-sand mixture $1 C: 3 S$ by volume was practically the

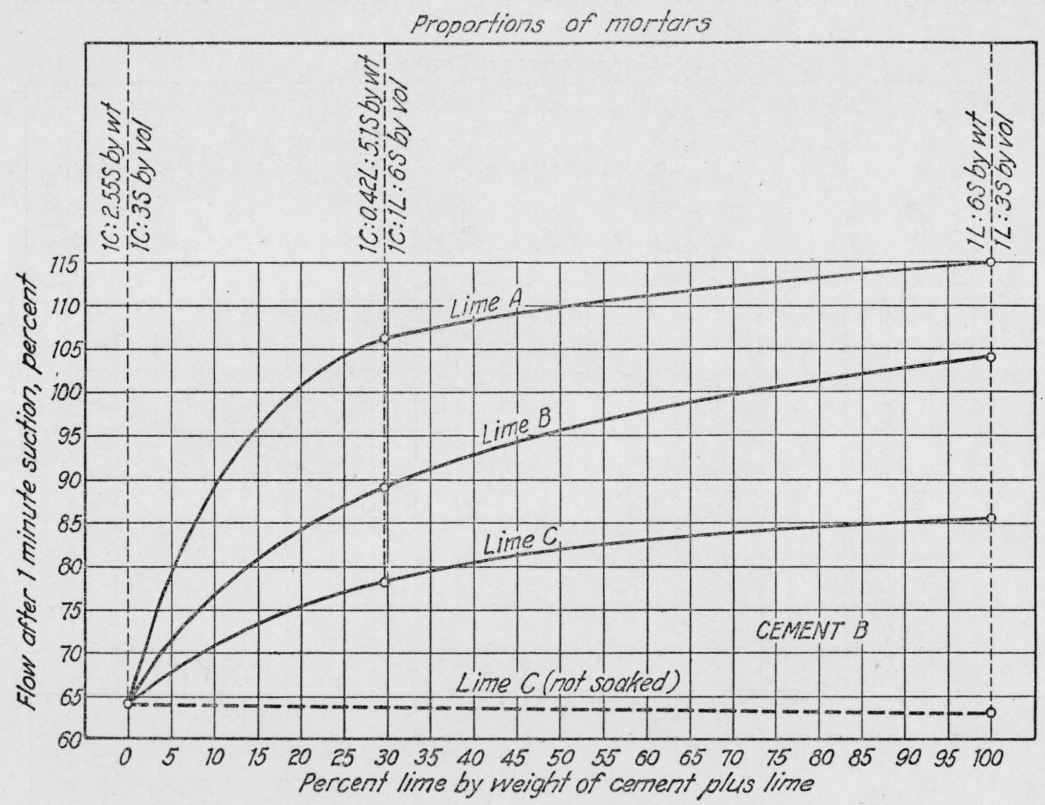

FIGURE. 8.-Relation between the flow after 1 minute suction of mortars resulting from the substitution of different limes for a cement of high specific surface and the percentage of limes substituted for the cement.

Specific surface of cement $B$ (high-early-strength) was $2,750 \mathrm{~cm}^{2} / \mathrm{g}$ and plasticities of lime putties $A, B$, and $C$ were greater than 600,280 , and 120 , respectively. Prior to suction all mortars were brought to a flow of 130 percent.

same as that obtained with the straight lime-sand mortar prepared with the unsoaked lime $C$.

\section{SUMMARX}

A survey was made of the soundness and plasticity of lime putties made from 43 commercial limes, including pulverized quicklimes and hydrated limes. Lime putties were used also in preparing lime and cement-lime mortars adjusted to a flow of 130 percent. Part of the water was then removed by a suction device and by contact with sand-lime brick and the resulting "flows after suction" were determined.

When the 43 lime putties were soaked 1 day prior to testing (by steaming lime-gypsum pats at $120 \mathrm{lb}$./in. ${ }^{2}$ for 2 hours), 7 of the 24 hydrated limes and 8 of the 19 quicklimes were classified as unsound. 
After soaking 3 days, four of the hydrated lime putties, and four of the quicklime putties were unsound.

The plasticity values of the 43 lime putties prepared by soaking limes for 1 day ranged from 50 to more than 600 , the most plastic putties being those prepared from quicklimes.

Nineteen of the putties had higher plasticities after 3 days of soaking than they did after 1 day of soaking, but six of them were less plastic.

The flows of lime mortars after 1 minute of suction varied from 73 to 117 percent.

In general, lime mortars prepared from quicklime putties gave higher flow values after suction than they did when prepared with hydrated limes.

Flow after suction of lime mortars (whether determined with a suction apparatus or with mortars which had been placed on sandlime brick) is dependent on the plasticity of the putty used in preparing the mortar.

Addition of a nonplastic dry hydrated lime increased the flow after suction of a portland cement mortar but little. Using the same lime as an aged putty gave higher flows after suction.

The flow after suction of cement-lime mortars depends far more on the properties of the lime than on the cement-lime ratio.

Washington, September 29, 1936. 